Vol. 8(1999): 309-318.

\author{
Research Note
}

\title{
Occurrence of arbuscular mycorrhizal fungi in different cropping systems at Cochabamba, Bolivia
}

\author{
Mauritz Vestberg \\ Agricultural Research Centre of Finland, Plant Production Research, Laukaa Research and Elite Plant Station, \\ Antinniementie 1, FIN-41330 Vihtavuori, Finland, e-mail: mauritz.vestberg@mtt.fi \\ Marcelo Cardoso and Anna Mårtensson \\ Swedish University of Agricultural Sciences, Department of Soil Science, PO Box 7014, SE-750 07 Uppsala, Sweden
}

\begin{abstract}
The occurence of arbusculeforming fungi in different cropping systems was investigated in the province of Cercado, Bolivia. The cropping systems included grain and mixed pasture systems, with or without fertilization and agrochemicals. Geographically, the soils were situated at $17^{\circ} 23^{\prime} 9^{\prime}$ ' southern latitude and 66 9'35" western longitude a mean height of $2600 \mathrm{~m}$ above sea level. Spores of four arbuscular mycorrhiza fungi-forming genera were observed; Glomus Tul. \& Tul., Entrophospora Ames \& Schneider, Sclerocystis Berk. \& Broome emend. Almeida \& Schenck and Scutellospora Walker \& Sanders. Glomus was the dominating genus, followed by Sclerocystis; Scutellospora and Entrophospora were observed occasionally. A cropping system consisting of a native pasture without any fertilization or other plant or soil treatments had the highest numbers of spores and the highest species richness, eight out of nine species identified. The mycorrhizal diversity measured with the ShannonWiener index did however not differ very much between cropping systems.
\end{abstract}

Key words: AMF spore densities, arbuscular mycorrhizal fungi, cropping systems, diversity index, Glomales

\section{Introduction}

Arbuscular mycorrhizal fungi (AMF) are amongst the most commonly occurring soil fungi (Gerdemann 1968) and are associated with about $80 \%$ of terrestrial plants in most vegetation types (Gianinazzi and Gianinazzi-Pearson 1986). Benefits of the mycorrhiza includes par- ticularly its contribution to nutrient uptake which has been studied extensively (Hayman 1983, Abbott et al. 1984, Thompson 1990). AMF fungal symbioses, however, not only increase plant nutrient uptake by extending the apparent soil volume available to the plants but improve the tolerance of plants to various biotic and abiotic factors, including pathogens (Gerdemann 1968, Jaizme-Vega et al. 1997) and physical stresses

(C) Agricultural and Food Science in Finland

Manuscript received November 1998 


\section{Vestberg, M. et al. Arbuscular mycorrhizal fungi in Bolivia}

such as high salt concentrations (Rosendahl and Rosendahl 1991) and drought (Goicoechea et al. 1997).

The arbuscular mycorrhizal fungi (AMF) form a unique order, the Glomales (Morton and Benny 1990), consisting of the six genera, i.e. Acaulospora Gerd. \& Trappe, Entrophospora Ames \& Schneider, Gigaspora Gerd. \& Trappe, Glomus Tul. \& Tul., Sclerocystis Berch \& Broome emend. Almeida \& Schenck and Scutellospora Walker \& Sanders. Surveys of species belonging to the Glomales have been conducted in tropical (Redhead 1977, Al-Garni and Daft 1990, Ganesan et al. 1991, Sieverding 1991), temperate (Gerdemann and Trappe 1974, Hall 1977, Walker et al. 1982) and arctic regions (Allen et al. 1987, Väre et al. 1997).

Although data are available on the occurrence of AMF in agricultural systems in eastern Europe, North America and Australia, there is little information concerning agricultural systems of other temperate regions. Most studies of the Glomales in South America have been conducted under tropical conditions (Sieverding 1990, Sieverding 1991, Cuenca et al. 1998). The purpose of this study was to collect, identify and culture species of the Glomales from a field experiment with different cropping systems at Cochabamba, Bolivia. To the authors' knowledge, this is the first report on species of the Glomales from Bolivia.

\section{Material and methods}

\section{Study site}

Soil samples for estimation of AMF spore densities and establishment of pure cultures of AMF were collected from six fields and a natural ecosystem belonging to the University of Mayor de San Simon (UMSS) in the area of La Tamborada, Cochabamba town, province of Cercado, Bolivia. The latitude and longitude of the sampling area are $17^{\circ} 23^{\prime} 09^{\prime \prime} \mathrm{S}$ and $66^{\circ} 09^{\prime} 35^{\prime \prime} \mathrm{W}$, respectively, and the mean altitude is $2600 \mathrm{~m}$ above sea level. The area has a dry, temperate climate with a mean annual rainfall and temperature of $460 \mathrm{~mm}$ and $17^{\circ} \mathrm{C}$, respectively. The soil samples were collected between 4 and 27 May 1994. soil samples from the top soil $(0-25 \mathrm{~cm})$ were collected along a diagonal line over the field. Each sample consisted of at least ten individual samples which were pooled and thoroughly mixed to form the final sample of one litre. Six soil samples were collected in a similar manner from the natural vegetation area. The soil samples were stored for two months in a refrigerator $\left(2-3^{\circ} \mathrm{C}\right)$ prior to estimation of spore numbers or establishment of AMF trap cultures.

\section{Cropping systems}

The UMSS experimental area at La Tamborada included 22 fields with a total area of 117.3 ha. Two fields with low-input cropping systems and three fields with high-input cropping systems were chosen from this area. Two natural ecosystems, a native pasture and a eucalyptus dominant wild ecosystem, were chosen for reference. The cropping systems were not replicated; they occurred only in one place. The size of the individual fields varied between 2.6 and 12.6 ha (Table 1). The experimental areas were all alkaline with $\mathrm{pH}\left(\right.$ in $\mathrm{H}_{2} \mathrm{O}$ ) varying between 7.4 and 8.6. The phosphorus $(\mathrm{P})$ contents of the soils, estimated as $\mathrm{NaHCO}_{3}$-extractable $\mathrm{P}$ (Olsen et al. 1954) were the highest, 45 and 32 ppm, respectively, in cropping systems 7 (high-input grain/ pasture) and 1 (native pasture), and the lowest in the natural ecosystem. The soil content of organic $\mathrm{C}$ was also the highest in cropping systems 1 and 7, 3.07\% and $1.22 \%$, respectively. The soil of each cropping system had a rather similar texture (fractions of sand, silt and clay), with the exception of field number 4 where the soil had a high content of clay (Table 2).

\section{Spore extraction}

Spores were extracted from field soil by wet sieving and decanting (Gerdemann and Nicolson 
Vol. 8 (1999): 309-318.

Table 1. Presentation of cropping systems at Cochabamba, Bolivia.

\begin{tabular}{|c|c|c|c|c|}
\hline $\begin{array}{l}\text { Cropping } \\
\text { Number }\end{array}$ & system & Rotation & $\begin{array}{l}\text { Use of fertilizers and } \\
\text { pesticides }\end{array}$ & $\begin{array}{l}\text { Size of } \\
\text { field, } \\
\text { ha }\end{array}$ \\
\hline 1 & Natural ecosystem & Native pasture & None & 2.5 \\
\hline 2 & Natural ecosystem & $\begin{array}{l}\text { Natural vegetation, } \\
\text { Eucalyptus dominating }\end{array}$ & None & Unknown \\
\hline 3 & $\begin{array}{l}\text { Low-input grain/ } \\
\text { pasture }\end{array}$ & $\begin{array}{l}\text { 1989-1991, maize } \\
\text { 1992, oats } \\
\text { 1993, alfalfa }\end{array}$ & Unknown & 3.6 \\
\hline 4 & Low-input grain & 1980-1994, maize & $\begin{array}{l}\text { Very low amounts of } \\
\text { animal manure, urea and P } \\
\text { fertilizers } \\
\text { Very low amounts of } \\
\text { herbicides used }\end{array}$ & 6.6 \\
\hline 5 & $\begin{array}{l}\text { High-input grain/ } \\
\text { pasture }\end{array}$ & $\begin{array}{l}\text { 1984-1990, alfalfa } \\
\text { 1991-1994, maize }\end{array}$ & $\begin{array}{l}\text { Animal manure (amounts } \\
\text { unknown) } \\
\text { Hormone herbicides used }\end{array}$ & 9.9 \\
\hline 6 & High-input grain & 1980-1994, maize & $\begin{array}{l}\text { Heavy applications of } \\
\text { animal manure }\end{array}$ & 12.6 \\
\hline 7 & $\begin{array}{l}\text { High-input grain/ } \\
\text { pasture }\end{array}$ & $\begin{array}{l}\text { 1977-1981, grass and } \\
\text { alfalfa } \\
\text { 1982-1993, maize } \\
\text { 1994, oats }\end{array}$ & $\begin{array}{l}\text { Maize fertilized with } \\
\text { approx. } 100 \mathrm{~kg} \text { P and urea- } \\
\text { N/year } \\
\text { Oats given } 9-10 \text { tons wet } \\
\text { weight of green manure/ha }\end{array}$ & 5.1 \\
\hline
\end{tabular}

1963) followed by centrifugation in water and in a $50 \%$ sucrose solution (Walker et al. 1982). A $1000-\mu \mathrm{m}$ and a $100-\mu \mathrm{m}$ sieve were used for wet sieving. After centrifugation the spores were transferred on a filter paper for examination under the dissecting microscope at magnifications up to 50 times with illumination by incident light from a fibre-optic, quartz-halogen light source

Table 2. Chemical and physical properties of soil collected from different cropping systems at Cochabamba, Bolivia. For details of cropping systems, see Table 1.

\begin{tabular}{cccccccc}
\hline $\begin{array}{c}\text { Cropping } \\
\text { system } \\
\text { nr }\end{array}$ & $\begin{array}{c}\text { Sand } \\
\%\end{array}$ & $\begin{array}{c}\text { Silt } \\
\%\end{array}$ & $\begin{array}{c}\text { Clay } \\
\%\end{array}$ & Texture $^{1)}$ & $\begin{array}{c}\mathrm{pH} \\
\left(\mathrm{H}_{2} \mathrm{O}\right)\end{array}$ & $\begin{array}{c}\left.\mathrm{P}^{2}\right) \\
\mathrm{mg} / \mathrm{kg} \text { soil }\end{array}$ & $\begin{array}{c}\mathrm{C} \\
\%\end{array}$ \\
\hline 1 & 32 & 32 & 36 & $\mathrm{CL}$ & 7.4 & 32.0 & 3.07 \\
2 & 28 & 42 & 30 & $\mathrm{CL}$ & 7.5 & 4.0 & 0.15 \\
3 & 49 & 22 & 29 & $\mathrm{SaCL}$ & 8.2 & 8.4 & 0.33 \\
4 & 10 & 16 & 74 & $\mathrm{C}$ & 8.6 & 15.0 & 0.15 \\
5 & 50 & 22 & 28 & $\mathrm{SaCL}$ & 7.4 & 22.0 & 0.88 \\
6 & 38 & 24 & 38 & $\mathrm{CL}$ & 7.6 & 10.0 & 0.61 \\
7 & 32 & 34 & 34 & $\mathrm{CL}$ & 7.9 & 45.0 & 1.22 \\
\hline
\end{tabular}

1) Texture: Sand (Sa), Clay (C), Silt (S), Loam (L)

2) Determined as $\mathrm{NAHCO}_{3}$-extractable $\mathrm{P}$ (Olsen et al. 1954) 


\section{Vestberg, M. et al. Arbuscular mycorrhizal fungi in Bolivia}

with a colour temperature of $3200 \mathrm{~K}$ (Walker et al. 1993). Spores were characterized and, when possible, identified to species using a high-power light microscope. Spores from trap cultures and pure cultures were extracted by wet sieving (500and $50-\mu \mathrm{m}$ sieves) and decanting and placed in a dish of water for examination under dissecting microscope and a high-power microscope. Mycorrhizal fungal diversity was calculated using the Shannon-Wiener index, which combines two components of diversity, i.e. species richness and evenness of individuals among the species (Krebs 1985).

\section{Fungal isolation and culturing}

Pot cultures for trapping AM fungi were established in October 1994 at the Department of Soil Sciences, Uppsala, Sweden. Seeds of Tagetes sp. were sown in a 1:1 dilution of original soil and sterilized sand. The pots were kept in a growth chamber under artificial light (16 h light, 260 $\mu \mathrm{mol} \mathrm{m} \mathrm{m}^{-2} \mathrm{~s}^{-1}$ ) at $18^{\circ} \mathrm{C}$ and $80 \%$ relative humidity. The trap cultures were checked for AM fungal growth by wet sieving in March 1995. Newly formed, similar looking spores of the Glomales were then used to establish multi-spore cultures (at the Laukaa Research and Elite Plant Station, Finland) in sealed transparent plastic bags $\left(\right.$ Sunbag $\left.^{\circledR}\right)$, incorporating a microfilter to allow gaseous exchange (Walker and Vestberg 1994). The cultures were intiated by placing approximately 20-30 spores directly on the root of young seedlings of Plantago lanceolata L. A mixture of steamsterilized sand and perlite $(9: 1)$ fertilized with $2 \mathrm{~g} \mathrm{l}^{-1}$ bone meal and given $5 \mathrm{~g} \mathrm{l}^{-1}$ Dolomite lime, was used as growth substrate. The pure culture were kept at $18 / 15^{\circ} \mathrm{C}$ (day/ night), 50-60\% relative humidity in a growth chamber with warm white artificial light (approx. $120 \mu \mathrm{mol} \mathrm{m} \mathrm{m}^{-2} \mathrm{~s}^{-1}$ ).

Details of original collection and isolation, resultant cultures and subcultures, and herbarium specimens were recorded in a database developed by C. Walker (Walker and Vestberg 1998). According to that database, each culture pot was given an 'Attempt' number (unique to each culture attempt made from any original sample) and culture number (sequential for subcultures from a particular attempt). Voucher specimens of fresh material from both trap cultures and from pure cultures were assessed as semi-permanent microscopic slides either in polyvinyl alcohol lacto-glycerol (PVLG) (Omar et al. 1979) or in PVLG with Melzer's reagent (5:1 v/v), (Walker et al. 1993) in the personal herbarium of the first author, each individual collection being given an accession number.

\section{Results}

\section{Spore density}

Total spore densities varied between 95 per 100 gram dry soil in the low-input cropping system 3 (maize, oats and alfalfa rotation) and 710 in the native pasture (cropping system 1) (Fig. 1a). Nine spore types of AMF belonging to three genera were extracted (Table 3). The genus Glomus occurred the most, $90 \%$ of all spores extracted, the figures for Sclerocystis and Scutellospora being only $9.8 \%$ and $0.2 \%$, respectively. Acaulospora Gerdemann \& Trappe, Gigaspora Gerdemann \& Trappe emend. Walker \& Sanders and Enthrophospora were not found. Three species, Glomus constrictum Trappe (Figs. 2 and 3), G. mosseae (Nicol. \& Gerd.) Gerdemann \& Trappe (Fig. 4) and a Sclerocystis $\mathrm{sp}$. corresponding in most characteristics to S. liquidambaris Wu \& Chen (Fig. 5), were found in soil from all cropping systems. Species richness was the highest in the native pasture with eight out of nine spore types. The number of spore types found in the other cropping systems varied between five and six (Table 3). In contrast to the total number of AMF spores and the number of species identified, the Shannon-Wiener diversity index differed little between cropping systems (Fig. 1b). 
Vol. 8 (1999): 309-318.
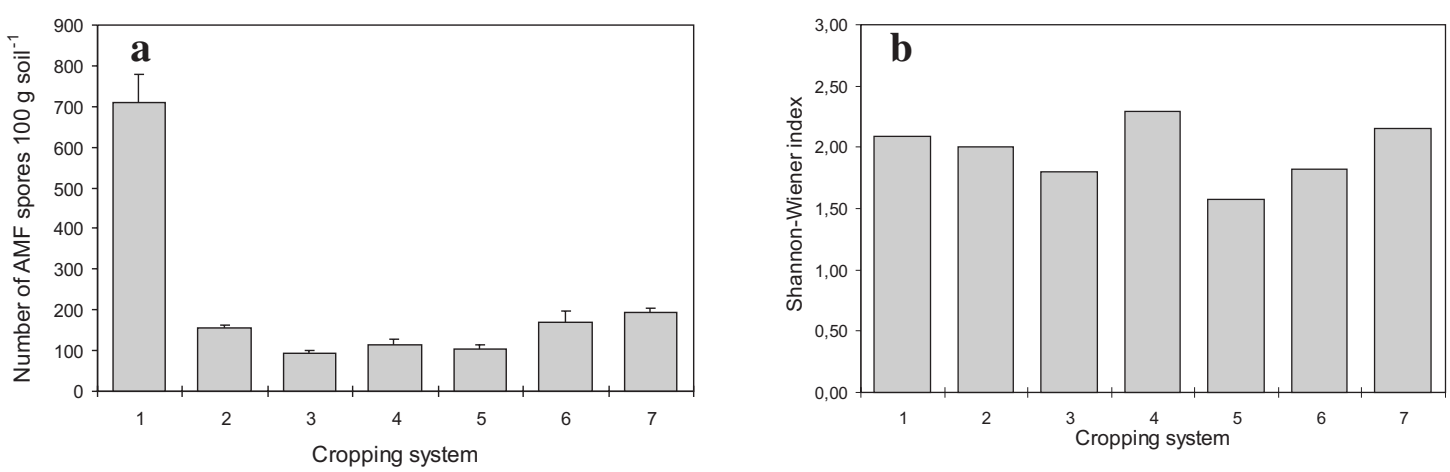

Fig. 1. Spore densities (a) and diversity index as measured by the Shannon-Wiener index (b) of arbuscular mycorrhizal fungi extracted in seven cropping systems (see Table 1) at Cochabamba, Bolivia. Bars represent standard deviations which, however, are only indicative of experimental error.

\section{Pure cultures of Bolivian AMF}

Trap cultures with Tagetes sp. yielded a G. microcarpum Tul. \& Tul.-like species (Fig. 6), G. mosseae, G. sp. "small white", G. sp. "shiny brown" and $S$. liquidambaris-like fungus, and these were used to initiate pure cultures. Culturing was successful except with the G. microcarpum-like fungus and with the S. liquidambarislike fungus. A commonly occurring Glomus sp. "shiny brown" proved to be G. constrictum, of which much darker spores were also found frequently by spore extraction. The Glomus sp. called "small white" remained unidentified. One of the cultures was first thought to be a pure culture of Glomus mosseae but appeared later to contain also the fungus Entrophospora infrequens (Hall) Ames \& Sneid. (Fig. 7). Attempts to culture E. infrequens alone failed, however. The resulting pure cultures were included in the AMF culture collection of the first author.

Table 3. Number of AMF spores (extracted by wet sieving, centrifugation and sugar floatation) in soil from different cropping systems at Cochabamba, Bolivia. For details of cropping systems, see Table 1.

\begin{tabular}{lrrrrrrrr}
\hline & \multicolumn{7}{c}{$\begin{array}{c}\text { Numbers of AMF spores/ 100 g dry soil } \\
\text { Cropping system }\end{array}$} \\
\cline { 2 - 8 } Fungus & 1 & 2 & 3 & 4 & 5 & 6 & 7 & Sum \\
\hline Glomus constrictum & 236 & 38 & 6 & 11 & 26 & 65 & 12 & 394 \\
G. hoi-aggregatum-like & 2 & 15 & 2 & 2 & & 3 & 12 & 36 \\
G. fasciculatum-like & 30 & & 25 & 6 & 4 & 37 & 27 & 137 \\
G. microaggregatum-like & 2 & & & & 2 & & & 4 \\
G. microcarpum-like & 2 & & & & & & 22 & 2 \\
G. mosseae & 110 & 17 & 25 & 18 & 33 & 28 & 22 \\
G. sp. "greyish" & 143 & & & 4 & & & 2 & 149 \\
Sclerocystis liquidambarum- like & 48 & 24 & 4 & 8 & 2 & 7 & 2 & 95 \\
Scutellospora sp. & & 1 & & & & & & 1 \\
\hline
\end{tabular}




\section{AGRICULTURAL AND FOOD SCIENCE IN FINLAND}

Vestberg, M. et al. Arbuscular mycorrhizal fungi in Bolivia

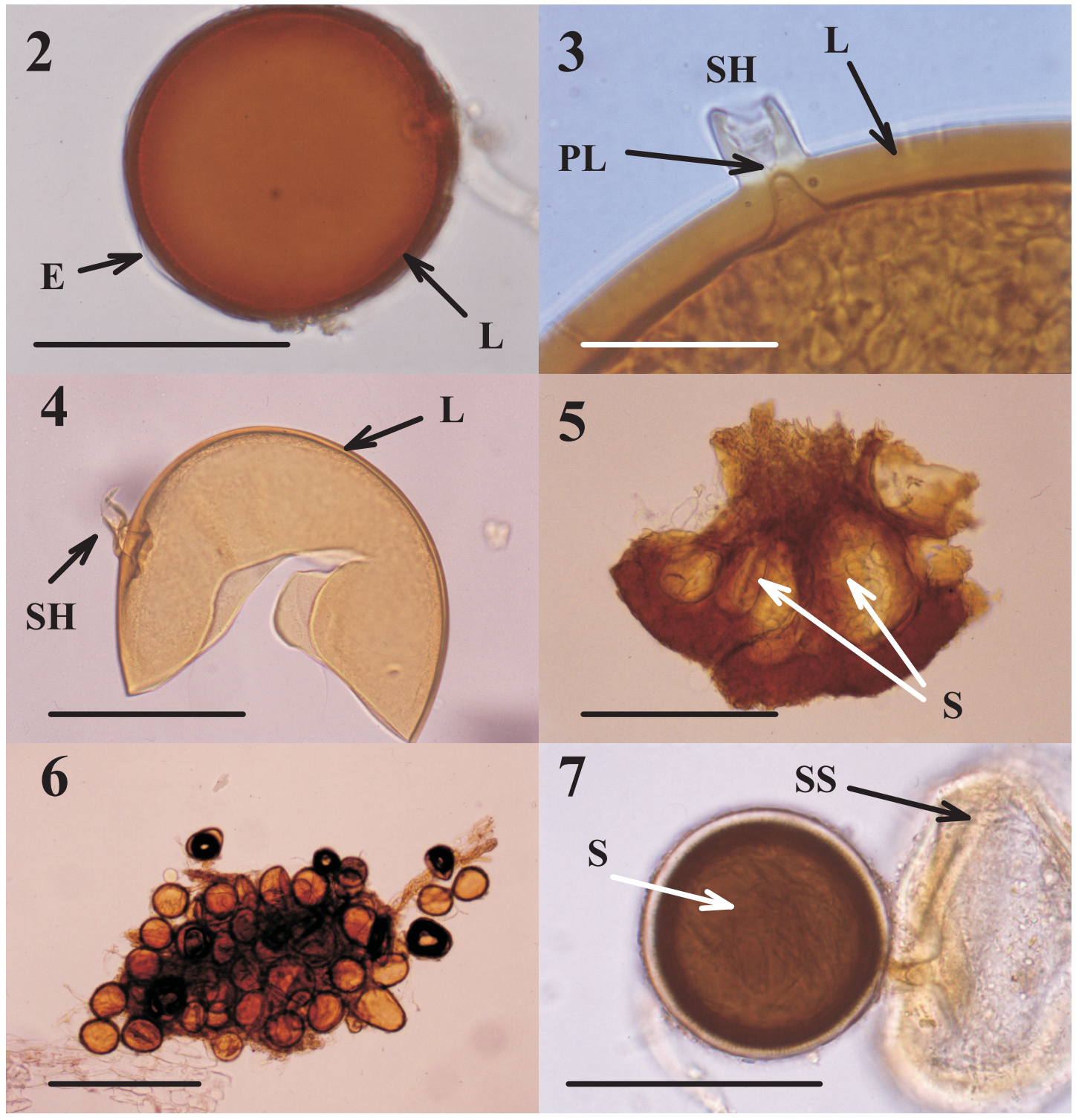

Fig. 2. Intact spore of Glomus constrictum showing a dark brown laminated wall component (L) and remnants of a hyaline outermost wall component (E). From pure culture attempt 775-1, bar $100 \mu \mathrm{m}$.

Fig. 3. Part of a spore of Glomus constrictum showing a laminated wall component (L), a short subtending hypha (SH) and a plug (PL) formed in it. From pure culture attempt 775-1, bar $30 \mu \mathrm{m}$.

Fig. 4. Crushed ectocarpic spore of Glomus mosseae from soil of cropping system 5 showing the funnel-like subtending hypha $(\mathrm{SH})$ and a relatively thin laminated wall component (L); bar $200 \mu \mathrm{m}$

Fig. 5. Part of a sporocarp of Sclerocystis liquidambaris showing individual spores (S). From cropping system 5; bar $200 \mu \mathrm{m}$.

Fig. 6. Sporocarp-like dense cluster of a Glomus sp. resembling G. microcarpum. From soil of cropping system 3; bar $300 \mu \mathrm{m}$.

Fig. 7. Spore (S) and sporoferous saccule (SS) of Entrophospora infrequens found in pure culture attempt 773-2, bar $100 \mu \mathrm{m}$. 
Vol. 8 (1999): 309-318.

\section{Discussion}

Spores of the genus Glomus were found most frequently followed by the genus Sclerocystis which was represented only by a species resembling S. liquidambaris (Wu and Chen 1987). The genus Scutellospora was found only once in the native ecosystem while the genera Acaulospora and Gigaspora were not detected at all. This result partly agres with the survey of locations for new species dscriptions by Allen (1991). According to this survey, new species of Glomus have been described in all climatic regions, but especially in the temperate regions, while species of the genera Acaulospora and Sclerocystis have been most frequently in the tropics. The absence of Acaulospora in this study might have been partly due to the use of too big sieves. Some small spores of Acaulospora will pass through a $100-\mu \mathrm{m}$ sieve. A better sieve size would have been $50 \mu \mathrm{m}$. On the other hand, small spores easily stick to soil particles and to each other which means that spores measuring 70-80 $\mu \mathrm{m}$ in diameter can also be detected when using a $100 \mu \mathrm{m}$ sieve. Repeated trapping might have revealed more slowly sporulating Acaulospora and Scutellospora as was found by Stutz and Morton (1996).

Species diversity was highest in the native pasture with eight out of nine AMF spore types found, while the other cropping systems exhibited 5-6 spore types out of nine. Similar results have been obtained in other investigations. Douds et al (1995) found that soil in low-input agriculture had greater populations of Glomus occultum Walker type spores and other Glomus spp., whereas the conventionally farmed soil had greater populations of G. etunicatum Becker \& Gerdemann-type spores. Another study (Douds et al. 1993) showed higher spore numbers of $G i$ gaspora gigantea (Nicol. \& Gerd.) Gerdemann $\&$ Trappe in low-input plots than in conventional plots. The fungus resembling S. liquidambaris was found in all cropping systems in our study despite different levels of fertilizer application and a $\mathrm{pH}$ exceeding 7.0. This result disagrees with the study of Sieverding (1990), according to which liming and fertilization of native tropical systems quickly made all the Sclerocystis spp. disappear.

The spore densities were the highest in the native pasture without any fertilizer or pesticide inputs, but much lower in the other low-input and high-input cropping systems as well as in the natural ecosystem. This result is in agreement with findings by Sieverding (1991), according to whom AMF spore densities are generally the highest low-input agricultural sites while the numbers are often lower at both native and highinput sites. Schenck and Siqueira (1987) also found more spores per unit of soil in agroecosystems than in native ecosystems, but a greater species diversity in the native ecosystems than in the agroecosystems. Douds et al. (1993) found higher populations of AMF spores in low-input plots than in conventionally farmed plots. Sattelmacher et al. (1991) found higher AMF root colonization in rye growing in an organic biological-dynamic farming system than in a conventionally managed high-input farming system.

The spore densities in this study must, however, be regarded only as indicative of real differences between the cropping systems because of the lack of replication of cropping systems across soil type. The standing crops also differed between systems. Maize was the standing crop in systems 4,5 and 6 , while oats and alfalfa were growing in system 7 and 3, respectively. Systems 1 and 2 had a mixture of plant species. Differences in host plants have been shown to result in differential AMF sporulation in the field (Kruckelmann 1975, Schenck and Kinloch 1980, McGraw and Hendrix 1984, Koske 1987, Janke and Peters 1993).

Spore densities of different cropping systems seemed not to correlate with differences in soil $\mathrm{P}$ which varied considerably, from 4 to $45 \mathrm{mg} \mathrm{P}$ $\mathrm{g} \mathrm{soil}^{-1}$. This result disagrees with the wellknown fact that increasing amounts of phosphorus has a negative impact on mycorrhiza (Antunes and Cardoso 1991, Arias et al. 1991, Bolan 1991, Fairchild and Miller 1990, Hung et al. 1990, Raju et al. 1990). Mårtensson and Carlgren (1993) 
Vestberg, M. et al. Arbuscular mycorrhizal fungi in Bolivia

found that the number of mycorrhizal spores decreased rapidly over time with increasing annual additions of a soluble phosphorus fertilizer. In our study there are indications that the amount of organic carbon in the soil better explains the differences in spore densities. The native pasture which had the highest spore density also had the highest content of organic carbon, $3.07 \%$, followed by cropping system 7 with $1.22 \%$. The rest of the cropping systems had soil with amounts of organic $\mathrm{C}$ below $1 \%$. A positive cor- relation between soil organic matter and mycorrhiza has been found also in other investigations (Saif 1986, Sieverding 1991, Toro and Sieverding 1986).

Acknowledgements. We wish to thank the University of San Simon, Bolivia, and in particular Dr Juan Vellot, for allowing us to collect soil samples from their experimental field. Special thanks are due also to Dr Chris Walker for invaluable help in identification of the fungi. The study was financially supported by a grant from the Swedish University of Agricultural Sciences (Minor Field Study).

\section{References}

Abbott, L.K., Robson, A.D. \& De Boer, G. 1984. The effect of phosphorus on the formation of hyphae in soil by the vesicular-arbuscular mycorrhizal fungus, Glomus fasciculatum. New Phytologist 97: 437-446.

Al-Garni, S.M. \& Daft, M.J. 1990. Occurrence and effectiveness of vesicular arbuscular mycorrhizas in agricultural soils from Saudi Arabia. Biological Agriculture and Horticulture 7: 69-80.

Allen, M.F. 1991. The Ecology of Mycorrhizae. Cambridge University Press, Cambridge, UK. 184 p.

-, Chambers, J.C., Connor, K.F., Allen, M.F. \& Brown, R.W. 1987. Natural re-establishment of mycorrhizae in disturbed alpine ecosystems. Arctic and Alpine Research 19: 11-20.

Antunes, V. \& Cardoso, E.J.B.N. 1991. Growth and nutrient status of citrus plants as influenced by mycorrhiza and phosphorus application. Plant and Soil 131: 11-19.

Arias, I., Koomen, I., Dodd, J., White, R.P. \& Hayman, D.S. 1991. Growth responses of mycorrhizal and nonmycorrhizal tropical forage species to different levels of soil phosphate. Plant and Soil 132: 253-260.

Bolan, N.S. 1991. A critical review on the role of mycorrhizal fungi in the uptake of phosphorus by plants. Plant and Soil 134: 189-207.

Cuenca, G., De Andrade, Z. \& Escalante, G. 1998. Arbuscular mycorrhizae in the rehabilitation of fragile degraded tropical lands. Biology and Fertility of Soils 26: 107-111.

Douds, D.D. Jr., Galvez, L., Janke, R.R. \& Wagoner, P. 1995. Effect of tillage and farming system upon populations and distribution of vesicular-arbuscular mycorrhizal fungi. Agriculture, Ecosystems and Environment 52: 111-118.

-, Janke, R.R. \& Peters, S.E. 1993. VAM fungus spore populations and colonization of roots of maize and soybean under conventional and low-input sustainable agriculture. Agriculture, Ecosystems and Environment 43: 325-335.

Fairchild, M.H. \& Miller, G.L. 1990. Vesicular-arbuscular mycorrhizas and the soil-disturbance-induced reduc- tion of nutrient absorption in maize. III. Influence of $\mathrm{P}$ amendments to soil. New Phytologist 114: 641650.

Ganesan, V., Ragupathy, S., Parthipan, B., Rajini Rani, D.B. \& Mahadevan, A. 1991. Distribution of vesicular-arbuscular mycorrhizal fungi in coal, lignite and calcite mine spoils of India. Biology and Fertility of Soils 12: 131-136.

Gerdemann, J.W. 1968. Vesicular-arbuscular mycorrhiza and plant growth. Annual Revue of Phytopathology 6: 396-418.

- \& Nicolson, T.H. 1963. Spores of mycorrhizal Endogone species extracted from soil by wet sieving and decanting. Transactions of the British Mycological Society 46: 235.

- \& Trappe, J.M. 1974. The Endogonaceae in the Pacific Nortwest. Mycologia Memoir 5: 1-76.

Gianinazzi, S. \& Gianinazzi-Pearson, V. 1986. Progress and headaches in endomycorrhiza biotechnology. Symbiosis 2: 139-149.

Goicoechea, N., Antolín, M.C. \& Sánchez-Díaz, M. 1997. Influence of arbuscular mycorrhizae and Rhizobium on nutrient content and water relations in drought stressed alfalfa. Plant and Soil 192: 261-268.

Hall, I.R. 1977. Species and mycorrhizal infections of New Zealand Endogonaceae. Transactions of the British Mycological Society 68: 341-356.

Hayman, D.S. 1983. The physiology of vesicular-arbuscular symbiosis. Journal of Botany 61: 944-963.

Hung, L.L., Sylvia, D.M. \& O’Keefe, D.M. 1990. Isolate selection and phosphorus interaction of vesiculararbuscular mycorrhizal fungi in biomass crops. Soil Science Society of America Journal 54: 762-768.

Jaizme-Vega, M.C., Tenoury, P., Pinochet, J. \& Jaumot, M. 1997. Interactions between the root-knot nematode Meloidogyne incognita and Glomus mosseae in banana. Plant and Soil 196: 27-35.

Koske, R.E. 1987. Distribution of VA mycorrhizal fungi along a latitudinal temperature gradient. Mycologia 79: 55-68.

Krebs, C.J. 1985. Ecology. The Experimental Analysis of 
Vol. 8 (1999): 309-318.

Distribution and Abundance. Third Edition, Harper \& Row Publishers, New York. 800 p.

Kruckelmann, H. W. 1975. Effects of fertilizers, soils, soil tillage, and plant species on the frequency of Endogone chlamydospores and mycorrhizal infection in arable land. In: Sanders, F.E., Mosse, B. \& Tinker, P.B. (eds.) Endomycorrhizas. Academic Press, New York and London. p. 511-525.

Mårtensson, A.M. \& Carlgren, K. 1993. Impact of phosphorus fertilization on VAM diaspores in two Swedish long-term field experiment. Agriculture, Ecosystems and Environment 47: 327-334.

McGraw, A.C. \& Hendrix, J.W. 1984. Host and fumigation effects on spore population densities of species of endogonaceous mycorrhizal fungi. Mycologia 76: $122-131$.

Morton, J.B. \& Benny, G.L. 1990. Revised classification of arbuscular mycorrhizal fungi (Zygomycetes): a new order, Glomales, two new suborders, Glomineae and Gigasporineae, and two new families, Acaulosporaceae and Gigasporaceae, with an emendation of Glomaceae. Mycotaxon 37: 471-491.

Olsen, S.R., Cole, C.V., Watanabe, F.S. \& Dean, L.A. 1954. Estimation of available phosphorus in soils by extraction with sodium bicarbonate. United States Department of Agriculture, Circular No 939: 1-19.

Omar, M.B., Bolland, L. \& Heather, W.A. 1979. A permanent mounting medium for fungi. Bulletin of the British Mycological Society 13: 31-32.

Raju, P.S., Clark, R.B., Ellis, J.R., Duncan, R.R. \& Maranville, J.W. 1990. Benefit and cost analysis and phosphorus efficiiency of VA mycorrhizal fungi colonizations with sorghum (Sorghum bicolor) genotypes grown at varied phosphorus levels. Plant and Soil 124: 199-204.

Redhead, J.F. 1977. Endotrophic mycorrhizas in Nigeria: Species of Endogonaceae and their distribution. Transactions of the British Mycological Society 69: 275-280.

Rosendahl, C.N. \& Rosendahl, S. 1991. Influence of vesicular-arbuscular mycorrhizal fungi (Glomus spp.) on the response of cucumber (Cucumis sativus L.) to salt stress. Environmental and Experimental Botany 31: 313-318.

Saif, S.R. 1986. Vesicular-arbuscular mycorrhizae in tropical forage species as influenced by season, soil texture, fertilizers, host species and ecotypes. Angewandte Botanik 60: 125-139.

Sattelmacher, B., Reinhard, S. \& Pomikalko, A. 1991. Differences in mycorrhizal colonization of rye (Secale cereale L.) grown in conventional or organic biological-dynamic farming systems. Journal of Agron- omy \& Crop Science 167: 350-355.

Schenck, N.C. \& Kinloch, R.A. 1980. Incidence of mycorrhizal fungi on six field crops in monoculture on a newly cleared woodland site. Mycologia 72: 445-455.

- \& Siqueira, J.O. 1987. Ecology of VA mycorrhizal fungi in temperate agroecosystems. In: Sylvia, D.M., Hung, L.L. \& Graham, J.H. (eds.) Mycorrhizae in the Next Decade - Practical Applications and Research Priorities. Proceedings of the $7^{\text {th }}$ North American Conference on Mycorrhizae, University of Florida, Gainsville, Florida, U.S.A., May 3-8, 1987. p. 2-4.

Sieverding, E. 1990. Ecology of VAM fungi in tropical agrosystems. Agriculture, Ecosystems and Environment 29: 369-390.

- 1991. Vesicular-arbuscular mycorrhiza management in tropical agrosystems. Deutsche Gesellschaft für Teknische Zusammenarbeit (GTZ), Eschborn $\mathrm{GmbH}$. $372 \mathrm{p}$.

Stutz, J.C. \& Morton, J.B. 1996. Successive pot cultures reveal high species richness of arbuscular endomycorrhizal fungi in arid ecosystems. Canadian Journal of Botany 74: 1883-1889.

Thompson, J.P. 1990. Soil sterilization methods to show VA-mycorrhizae aid $\mathrm{P}$ and $\mathrm{Zn}$ nutrition of wheat in Vertisols. Soil Biology and Biochemistry 22: 229-240.

Toro, T.S. \& Sieverding, E. 1986. Evaluación cuantitativa y cualitativa de hongos formadores micorriza vesiculo arbuscular en la región de Mondomo, Colombia. Suelos Ecuatoriales 16: 122-129.

Väre, H., Vestberg, M. \& Ohtonen, R. 1997. Shifts in mycorrhiza and microbial activity along an oroarctic altitudinal gradient in Northern Fennoscandia. Arctic and Alpine Research 29: 93-104.

Walker, C. \& Vestberg, M. 1994. A simple and inexpensive method for producing and maintaining closed pot cultures of arbuscular mycorrhizal fungi. Agricultural Science in Finland 3: 233-239.

- \& Vestberg M. 1998. Synonymy amongst the arbuscular mycorrhizal fungi: Glomus claroideum, G. maculosum, G. multisubstensum and G. fistulosum. Annales of Botany 82: 601-624.

-, Gianinazzi-Pearson, V. \& Marion-Espinasse, H. 1993. Scutellospora castanea, a newly described arbuscular mycorrhizal species. Cryptogamie, Mycologie 14: 279-286.

-, Mize, C.W. \& McNabb, H.S. 1982. Populations of endogonaceous fungi at two locations in lowa. Canadian Journal of Botany 60: 2518-2529.

Wu, C.-G. \& Chen, Z. 1987. The Endogonaceae of Taiwan. II. Two new species of Sclerocystis from Taiwan. Transactions of the mycological Society of the Republic of China 2: 73-83. 
Vestberg, M. et al. Arbuscular mycorrhizal fungi in Bolivia

\title{
SELOSTUS
}

\section{Arbuskelimykorritsasienten esiintyminen eri viljelyjärjestelmissä Cochabambassa, Boliviassa}

\author{
Mauritz Vestberg, Marcelo Cardoso ja Anna Mårtensson \\ Maatalouden tutkimuskeskus ja Ruotsin maatalousyliopisto
}

Tutkimuksessa selvitettiin arbuskelimykorritsasienten (AMS) esiintymistä Mayor de San Simon -yliopiston viljelyjärjestelmäkokeessa Cochabamban kaupungissa, Boliviassa. Alue sijaitsee n. 2600 metrin korkeudessa ja siellä vallitsee kuivahko lauhkea ilmasto. Maanäytteitä kerättiin toukokuussa 1994 viideltä peltolohkolta, yhdeltä luonnonlaitumelta ja yhdeltä viljelemättömältä alueelta, jossa oli eukalyptuspuiden alla luontaista kasvillisuutta. Maanäytteistä laskettiin AMS-itiöiden määrät ja sienet pyrittiin luokittelemaan myös lajin mukaan. AM-sieniä pyydystettiin maasta myös Tagetes-kasvin avulla. Joistakin sienilajeista perustettiin puhdasviljelmiä heinä- ratamon juuristoon.

Tutkimuksessa selvitettiin ensimmäisen kerran AM-sienten esiintymistä Boliviassa. Alueelta löydettiin neljään sukuun kuuluvia sienilajeja; Glomus, Entrophospora, Sclerocystis ja Scutellospora. Glomussukuun kuuluvia sienilajeja määritettiin ylivoimaisesti eniten $(90 \%)$. Luonnonlaitumella maassa oli yli kolme kertaa enemmän AMS-itiöitä kuin eri tavalla lannoitetuissa peltolohkoissa, joissa viljeltiin maissia, palkokasveja ja heinäkasveja. Myös viljelemätön luonnonkasvillisuuden alue sisälsi vähemmän AMS-itiöitä kuin luonnonlaidun. 
